\title{
Obraz XIX-wiecznego polskiego szkolnictwa położniczego na łamach „Archiwum Historii i Filozofii Medycyny" z lat 1924-2010'
}

„Archiwum Historii i Filozofii Medycyny” jest najstarszym polskim periodykiem poświęconym dziejom medycyny w Polsce i na świecie. Jego utworzenie związane jest z osobą prof. Adama Wrzoska². Ten wybitny naukowiec uważał, że utworzenie „Archiwum” było koniecznością, ponieważ „Historia i filozofia medycyny nie tylko zostały wprowadzone jako egzaminacyjne dla ubiegających się u nas o stopień doktora medycyny, a to rozporządzeniem Ministra Oświaty z dnia 18 października 1920 r. w sprawie organizacji studiów lekarskich w uniwersytetach państwowych,

* Dr, Zakład Pedagogiki Społecznej, Instytut Pedagogiki i Psychologii, Wydział Pedagogiczny i Artystyczny, Uniwersytet Jana Kochanowskiego w Kielcach, 25-029 Kielce, ul. Krakowska 11.

1 Analizie poddano wszystkie numery periodyku z lat 1924-2010, interesujące nas treści występowały jednak tylko do $2002 \mathrm{r}$.

2 Adam Wrzosek (1875-1965) - wybitny polski lekarz, patolog, antropolog i historyk medycyny. Był związany z największymi polskimi ośrodkami akademickimi: najpierw od $1901 \mathrm{r}$. jako asystent, a od 1910 r. jako profesor z Uniwersytetem Jagiellońskim, na którym wykładał historię medycyny, później od 1918 r. z Uniwersytetem Warszawskim, od 1920 r. do końca życia z Uniwersytetem w Poznaniu, na którym zorganizował najpierw Zakład Historii i Filozofii Medycyny, a później Zakład Antropologii. W latach 1920-1923 brał udział w tworzeniu Wydziału Lekarskiego na Uniwersytecie Wileńskim. Na tej uczelni wykładał w latach 1935-1939. Był założycielem „Archiwum Historii i Filozofii Medycyny”, pierwszego polskiego pisma naukowego poświęconego dziejom tej dziedziny nauki (1924), Koła Miłośników Historii Medycyny i Nauk Przyrodniczych w Poznaniu (1925), Polskiego Towarzystwa Antropologicznego (1925), a ponadto - głównym organizatorem i wykładowcą Wydziału Lekarskiego tajnego Uniwersytetu Ziem Zachodnich z siedzibą w Warszawie, działającego w czasie II wojny światowej. Od 1930 r. członek PAU. Napisał około 500 prac naukowych z różnych dziedzin. Z. M a ć k o wi iak, Teoretyczny i praktyczny wkład Adama Wrzoska do historii filozofii medycyny w Polsce, „Archiwum Historii i Filozofii Medycyny" [dalej: AHiFM-I] 1986, z. 2, s. 231-254; http://portalwie-dzy.onet.pl/70308. wrzosek_adam,haslo.html [dostęp 1.10.2011]. 
lecz rzeczy, wchodzące w zakres tych przedmiotów mogą być tematem rozpraw doktorskich" ${ }^{3}$. Kwartalnik ten był z kolei siódmym na świecie czasopismem (po wydawanych w USA, Francji, Niemczech, Hiszpanii, Danii i Włoszech), poświęconym wyłącznie historii medycyny ${ }^{4}$.

Pierwszy tom „Archiwum Historii i Filozofii Medycyny” ukazał się w Poznaniu w 1924 r., składał się z 4 zeszytów i liczył 422 strony $^{5}$. Wszystkie prace publikowane na łamach pisma ujęte były w osiem działów: historia medycyny, filozofia medycyny, pamiętniki i listy, drobne artykuły, sprawozdania i oceny, wiadomości różne, sprostowania, skorowidz imion i nazwisk. Dział dziewiąty obejmował spis prenumeratorów (zamieszczono 346 nazwisk) ${ }^{6}$. Pismo to przez krytyków od razu zostało pozytywnie ocenione. Wyrazem tej opinii były m.in. słowa doktora Zygmunta Srebrnego, który w „Warszawskim Czasopiśmie Lekarskim” napisał: „Zeszyt I tomu I «Archiwum Historii i Filozofii Medycyny» stanowi świetną zapowiedź wydawnictwa, którego potrzebę odczuwał każdy światły lekarz polski"7. Podobną ocenę zeszytu I i 2 „Archiwum” ogłosił Wiktor Janusz w „Polskiej Gazecie Lekarskiej”, gdzie napisał: „Bogato urozmaicona treść każdego zeszytu jako też wytworna szata zewnętrzna zjednały dla «Archiwum» niewątpliwie sympatię ogółu oraz dostateczną ilość prenumeratorów dla utrwalenia bytu swego w czasopiśmiennictwie naszym"8.

W 1925 r. nastąpiła zmiana tytułu czasopisma na „Archiwum Historii i Filozofii Medycyny oraz Historii Nauk Przyrodniczych". Była ona podyktowana dostosowaniem profilu pisma do napływających masowo do wydawnictwa artykułów z zakresu historii nauk przyrodniczych, poruszających zagadnienia sposobów stosowania dawnych środków leczniczych w medycynie ludowej i oficjalnej oraz dziejów organizacji zawodu farmaceutycznego. Pod zmienionym tytułem pismo ukazywało się w latach 1925-1939 oraz w roku $1948^{9}$.

Pomimo wielu słów uznania i dużej ilości materiałów o różnej tematyce przeznaczonych do druku, pismo w pierwszych latach swego istnienia borykało się z problemami finansowymi. Miała na to wpływ m.in. niewielka liczba prenumeratorów. Nie pomagały nawet pożyczki przyznawane wydawnictwu oraz ofiarność społeczeństwa. W 1929 r. sytuacja czasopisma była drastyczna. Rękopisy do druku przyjmowano pod warunkiem, że autor pokryje część kosztów wydania artyku-

${ }^{3}$ A. Wr zo s e k, Zadania i zamierzenia polskiego „Archiwum Historii Medycyny i Filozofii Medycyny", AHiFM-I 1924, z. I, s. 10.

${ }^{4}$ G. W r o n a, Naukowe czasopisma medyczne i farmaceutyczne w Polsce w latach 1918-1939, „Rocznik Historii Prasy Polskiej” 2001, t. 4, s. 52.

5 T. Marcink owski, Tematyka przyrodnicza w „Archiwum Historii i Filozofii Medycyny oraz Historii Nauk Przyrodniczych”, „Archiwum Historii Medycyny” [dalej: AHM] 1975, z. I, s. 15; B. B u jało wska, Wykład lekarzy wielkopolskich do historii medycyny i prace historyczno-medyczne na łamach „Nowin Lekarskich”, tamże, s. 23.

6 S. Ko n o p k a, Profesor doktor Adam Wrzosek, redaktor i wydawca „Archiwum Historii i Filozofii Medycyny" w latach 1924-1949, AHM 1975, z. I, s. 5.

7 Tamże, s. 3.

8 Tamże, s. 5.

${ }^{9}$ W. Gło w a c ki, Pharmaceutica na łamach „Archiwum Historii Medycyny” (1924-1973), AHM 1975, z. I, s. 19. 
łu. Tego rodzaju trudności przeżywało pismo aż do 1939 r. Do tego czasu wydano osiemnaście tomów. W tym okresie doszło też do ostatecznego ukształtowania programu pisma. Ujęto go ostatecznie w cztery działy. W pierwszym zamieszczano prace naukowe z zakresu historii medycyny w ogóle (w szczególności polskiej) - drukowano tu artykuły, rozprawy i monografie historyczne, dotyczące dziejów uczelni i towarzystw naukowych lekarskich oraz nauczania medycyny. W drugim dominowały rozprawy z filozofii i historii nauk przyrodniczych, prace profesorów filozofii. W trzecim publikowano pamiętniki lekarzy w całości lub fragmenty oraz listy znakomitych uczonych medyków. Czwarty rozdział zawierał sprawozdania z ruchu naukowego w zakresie historii i filozofii medycyny w Polsce i zagranicą oraz życiorysy sławnych lekarzy ${ }^{10}$.

W czasie II wojny światowej pismo zawiesiło działalność wydawniczą. Po jej zakończeniu władze Polski Ludowej zlikwidowały wykłady z historii medycyny. Rząd nie interesował się czasopismem. Środowiska medyczne zabiegały o jego wznowienie, jednak brak środków materialnych sprawił, że udało się wydać w 1948 r. tylko jeden tom. Stało się to dzięki determinacji Adama Wrzoska, który niezrażony odmową pomocy ze strony Poznańskiego Towarzystwa Miłośników Historii Medycyny poszukiwał innych źródeł na wznowienie i sfinansowanie wydawnictwa. Pieniądze na ten cel przekazał do budżetu Lekarskiego Instytutu Naukowo-Wydawniczego Stanisław Konopka, serdeczny przyjaciel Adama Wrzoska. Druk tomu XIX trwał 2 lata, a gdy go już ukończono, prof. Wrzosek pisał w liście z dnia 22 grudnia 1949, że „Tom XIX leży w Drukarni Uniwersytetu Poznańskiego gotowy do wysyłki, lecz Drukarnia nie może się doczekać pozwolenia Urzędu Kontroli Prasy i Wydawnictw na rozpowszechnienie tego tomu Archiwum"11. Tom XIX dotarł do rąk odbiorców dopiero $w$ drugiej połowie 1950 r. ${ }^{12}$

Wznowienie cyklicznego wydawania pisma nastąpiło dopiero w roku 1957, kiedy wyszedł tom XX. Redaktorem naczelnym „Archiwum” został Stanisław Konopka (sprawował tę funkcję do 1972 r.), historyk medycyny, a także bibliotekarz i bibliograf ${ }^{13}$. Pismo zaczęło się ukazywać pod zmienionym tytułem - jako „Archiwum Historii Medycyny” (nazwa ta funkcjonowała do 1985 r.). Na jego łamach ukazywały się prace poświęcone tematyce społecznej, ochronie zdrowia, dziejom organizacji i funkcjonowaniu placówek służby zdrowia ${ }^{14}$. Od 1973 r. redaktorami pisma byli kolejno: Jan Władysław Chojna (1973), Tadeusz Bilikiewicz (1974-1981), Romuald Wiesław Gutt (1982-1988), Andrzej Środka (1989-1991), Tadeusz Brzeziński (1992-1997), Henryk Gaertner (1998-2000), Zdzisław Gajda (2000-2007), Roman Meissner (2007-2010) ${ }^{15}$. Obecnie redaktorem naczelnym

10 75-lecie „Archiwum Historii i Filozofii Medycyny” (I924-1999), AHiFM-I 1999, z. 1-2, s. 2; A. Wrzos e k, Zadania i zamierzenia..., s. 6-11.

11 S. Kon o k ka, Profesor doktor Adam Wrzosek..., s. 8.

12 Tamże, s. 9; S. Kon opka, Działalność naukowa, redakcyjna i wydawnicza prof. Adama Wrzoska w świetle jego wypowiedzi i listów, nie ogłoszonych w druku, AHM 1982, z. 1-4, s. 14.

13 H. B oj c z u k, Stanisław Konopka, historyk medycyny, AHiFM-I 1983, z. 4, s. 447.

14 S. Miło s z, O niektórych aspektach społecznych służby zdrowia w świetle prac zamieszczonych w „Archiwum Historii Medycyny”, AHM 1975, z. I, s. 11.

15 75-lecie..., s. I. 
jest Andrzej Grzybowski ${ }^{16}$. Wielokrotnie zmieniana była siedziba redakcji „Archiwum". Najpierw znajdowała się w Poznaniu, później w Warszawie, następnie w Szczecinie, potem w Krakowie, a obecnie jest w Poznaniu. Wpływały na to zmiany redaktorów naczelnych i wydawców. Obecną historyczną nazwę przywrócono w 1985 r., „na podstawie uchwały Walnego Zgromadzenia Członków Polskiego Towarzystwa Historii Medycyny na XIII Zjeździe w Katowicach za czasów sprawowania funkcji redaktora naczelnego przez prof. Romualda Wiesława Gutta"17.

„Archiwum Historii i Filozofii Medycyny” jest organem Polskiego Towarzystwa Historii Medycyny i Farmacji, „czasopismem naukowym typu humanistycznego, przeznaczonym do gromadzenia faktów z zakresu historii medycyny i rozwoju myśli lekarskiej w odniesieniu przede wszystkim do przeszłości polskiej. Jest pismem naukowym"18. Za pierwszy swój obowiązek uważało zawsze publikację prac z zakresu historii medycyny ojczystej. Na jego łamach swoje dokonania naukowe popularyzowali wybitni polscy lekarze, historycy i filozofowie, którzy interesowali się rozwojem historii medycyny. Wydawano tu także rozprawy, życiorysy, listy, sprawozdania, prace poświęcone dziejom lekarskim ${ }^{19}$. Czasopismo było i jest informatorem medycznym, pomocnym w kształceniu nowej kadry lekarskiej.

Mimo iż położnictwo stanowi najstarszą dziedzinę medycyny, na łamach „Archiwum Historii i Filozofii Medycyny” nie poświęcono mu zbyt wiele miejsca. Trudno też znaleźć informacje na temat fachowego przygotowania do pracy zawodowej pierwszych akuszerek. Niemniej ze wzmianek zawartych w różnych tekstach można nakreślić schematyczny obraz szkolnictwa położniczego funkcjonującego na ziemiach polskich w XIX i na początku XX w.

Stan pomocy położniczej przed założeniem pierwszych szkół akuszerek przedstawiał się dramatycznie. Ludność, zwłaszcza wiejska, nigdy nie korzystała z pomocy lekarza, bardzo rzadko z usług cyrulika. Najczęściej osoby chore skazane były na lecznictwo ludowe i dobrodziejstwo znachora ${ }^{20}$. Ludność polska była biedna, ciemna i zacofana. Stwarzało to warunki do leczenia pokątnego, którym zajmowali się znachorzy, guślarze, a odbieranie porodu, czyli tzw. „babienie” spoczywało głównie w rękach kobiet z ludu. Prawie do końca XVIII w. porody odbierały proste wiejskie kobiety, które nie miały żadnego przygotowania medycznego, a posługę przy rodzących traktowały jako możliwość zdobycia dodatkowych środków do życia. Swoje umiejętności i wiedzę w tym zakresie opierały głównie na własnym doświadczeniu i wieloletniej praktyce. Były to kobiety, przeważnie w starszym wieku, które już same wielokrotnie rodziły. Brak fachowej wiedzy z zakresu sztuki położniczej, opieki nad położnicą i narodzonym dzieckiem miał wpływ na to, że kobiety te umiały pomóc rodzącej jedynie w przypadku, gdy akcja porodowa przebiegała prawidłowo. Rola „bab” podczas porodu ograniczała się w za-

\footnotetext{
16 http://www.ahifm.pl [dostęp 10.10.2011].

17 75-lecie..., s. I; Do Czytelników, Autorów, Recenzentów!, AHiFM-I 2001, z. I, s. I.

18 Do Czytelników..., s. I.

19 T. O s tro w s k a, 50-lecie „Archiwum Historii Medycyny”, AHM 1973, z. 4, s. 231.

${ }^{20}$ K. B roże k, Położnictwo i ginekologia ludowa górali Beskidu Śląskiego, AHM 1971, z. 2,
} s. 203. 
sadzie do wykonania najprostszych czynności: odebrania rodzącego się dziecka, przecięcia i zawiązania pępowiny oraz umycia i zawinięcia noworodka. Natomiast podczas porodów patologicznych „babki” wykazywały się niestety bezradnością i uciekały się do wykorzystywania wróżbiarstwa, zabobonów, przesądów i wierzeń ludowych. Takie praktyki nie spotykały się ze sprzeciwem tych, do których były wezwane, gdyż całe ówczesne polskie społeczeństwo, a zwłaszcza ludność wiejska, głęboko wierzyło w skuteczność takich praktyk. Pomoc rodzącej przy porodzie patologicznym zazwyczaj była bezskuteczna, a finałem była najczęściej śmierć matki i dziecka²1.

Poród był tym procesem fizjologicznym, przy którym mogły asystować tylko inne kobiety - wyłącznie zamężne, a najlepiej starsze doświadczone niewiasty. Ich zadaniem było zadbanie, aby dopełnić wszystkich związanych w tym aktem praktyk. Wierzono, że zachowanie pewnych procedur ludowych przyczynia się do szczęśliwego rozwiązania ${ }^{22}$. Obowiązkowo przed rozpoczęciem akcji porodowej, gdy pojawiły się pierwsze bóle, należało zaciemnić okna izby, w której leżała położnica i nad nimi oraz nad drzwiami powiesić różnego rodzaju zioła poświęcone w Boże Ciało. Zwyczaj ten miał uchronić rodzącą i jej dziecko przed działaniem złych duchów. Aby poród był lżejszy, rodzącą karmiono rosołem (ugotowanym koniecznie z całego koguta). Kazano jej też wdychać opary palącego się w płaskim naczyniu spirytusu, a następnie przeprowadzano ją trzykrotnie przez przetak, położony na środku izby. Ciężarna mogła chodzić do chwili odejścia wód płodowych, potem „baby” kładły ją przeważnie do łóżka, a następnie smarowały „części rodne” niesolonym masłem lub olejkiem migdałowym. Na szyi rodzącej wiązały bardzo mocno chusteczkę, „aby przez to gruczołowate i wolowate szyjne napuchnienie zatamować"23. Gdy pojawiły się bóle parte, naciskały na powłoki brzuszne i kazały rodzącej przeć. Po urodzeniu się dziecka szybko przecinały i zawiązywały pępowinę, a niemowlę kąpały i zawijały w płótno. Matce podawały do picia wódkę z naparem z ziół, np. rumianku, melisy lub ślazu. Było to uniwersalne lekarstwo przeciwko różnym dolegliwościom bólowym, występującym po porodzie. Brzuch położnicy mocno owijały płóciennymi opaskami, aby jak najszybciej przywrócić mu pierwotny wygląd24.

Jeżeli poród przebiegał prawidłowo i nie wystąpiły żadne komplikacje poporodowe, to położnica szóstego dnia wstawała z łóżka, jednak nie mogła opuszczać swojego domu przed dopełnieniem obrządku kościelnego, zwanego wywodem. Do tego czasu uważana była za nieczystą. Oczyszczenie następowało po chrzcie dziecka. Działo się to zazwyczaj po upływie sześciu tygodni od rozwiązania ciąży ${ }^{25}$.

Asystujące przy porodzie „baby” nie troszczyły się o zapewnienie odpowiednich warunków higienicznych. Wręcz przeciwnie, nie było w zwyczaju, aby „babka” myła ręce przed udzieleniem pomocy położnicy. Dlatego często dochodziło do zakażeń, doprowadzających do śmierci rodzących kobiet.

${ }^{21}$ Z. Fila r, Pomoc położnicza przed założeniem szkół położnictwa, AHM 1959, z. 4, s. 514.

22 Tamże, s. 518.

23 Tamże, s. 519.

24 Tamże, s. 521.

${ }^{25}$ K. B r oż e k, Położnictwo..., s. 204. 
Tragiczny był los rodzących, u których płód przyjmował złe ułożenie. Działalność babek samouczek w takich sytuacjach przynosiła wiele szkody, bólu i cierpienia. Nie umiały pomóc, ponieważ nie miały podstawowej wiedzy na temat budowy narządów rodnych kobiety i położenia noworodka. Nie potrafiły też zapobiec komplikacjom i niebezpieczeństwom, jakie niósł ze sobą poród patologiczny. Podczas takich porodów dochodziło często do wręcz barbarzyńskich praktyk, wmawiania rodzącej i jej rodzinie, że taka sytuacja jest następstwem gniewu bogów, karą za złe czyny. Aby odwrócić nieprzychylność losu, „podawano rodzącej do trzymania w ustach welon Matki Bożej, to jest skrawki płótna dostarczane kobietom przez najrozmaitsze zakony lub też opasywano biodra paskiem świętego Franciszka, a na piersiach zawieszano szkaplerze"26. W przypadku wypadnięcia drobnej części, na przykład rączki płodu, kobiety odbierające poród pociągały za tę część. Gdy postępowanie takie nie przyniosło efektu, postanawiały zazwyczaj (nie zwracając uwagi na zimno) wywieźć rodzącą na drogę i dotąd prowadzać, aż płód sam się prawidłowo ułoży. Umęczone, obolałe kobiety zazwyczaj po wielu dniach takich męczarni umierały, często z powodu zakażenia wewnątrzmacicznego lub wykrwawienia się. Tragicznie przebiegały też porody, w których płód był w położeniu podłużnym, miednicowym. Taki poród najczęściej kończył się urwaniem główki noworodka ${ }^{27}$.

Brak wiedzy, higieny i pewnych elementarnych wręcz umiejętności, a także zarozumiałość i bezduszność kobiet trudniących się położnictwem prowadziła do ciężkich uszkodzeń zarówno rodzącej, jak i dziecka. Noworodki często rodziły się z uszkodzonymi częściami ciała: złamanymi obojczykami, zniekształceniami czaszki, zwichniętymi stawami biodrowymi, otarciami naskórka. Matki umierały podczas porodu lub będąc już w połogu z powodu zakażenia, często zostawiając kilkoro wcześniej urodzonych dzieci. Kobiety zajmujące się sztuką „babienia” były krzewicielkami zabobonu wśród prostej ludności wsi, nie miały żadnych kwalifikacji zawodowych i moralnych ${ }^{28}$.

Ten stan rzeczy niepokoił postępowe grupy społeczeństwa, zdające sobie sprawę z tego, że wielu ludzkich tragedii dałoby się uniknąć, gdyby można było zapewnić prostemu ludowi fachowo przygotowaną do odbierania porodów akuszerkę. Widzieli, w jaki sposób kobiety z ludu udzielają pomocy położniczej, ile bólu, cierpienia i krzywdy wyrządzają rodzącym i noworodkom. Rozumieli potrzebę wyrwania położnicy z rąk brudnych bab i oddania jej pod opiekę wyszkolonej akuszerce, która posiadałaby wiedzę położniczą, zarówno teoretyczną, jak i praktyczną ${ }^{29}$.

Jak wynika z kilku artykułów, pierwsze inicjatywy w zakresie tworzenia szkół położniczych wyszły z kręgów arystokratycznych. Reformatorką w swoich dobrach była niewątpliwie księżna Anna z Sapiehów Jabłonowska. Przeprowadziła ona reformy gospodarcze w swoich dobrach, a podążając za ówcześnie panującym

26 Z. F ila r, Pomoc położnicza..., s. 523.

27 Tamże, s. 525.

28 Tamże, s. 526.

29 Tamże, s. 535. 
trendem społecznym, dotyczącym pomocy ubogim, postanowiła podnieść poziom życia i zdrowia swoich poddanych. Jedną z takich inicjatyw, mającą służyć pomocy zdrowotnej dla jej włościan, było założenie w 1783 r. w Siemiatyczach szkoły akuszerek, zwanej szkołą babienia ${ }^{30}$. Jabłonowska dostrzegła potrzebę założenia takiej instytucji, ponieważ widziała, jak wiele młodych kobiet umiera w czasie porodu tylko dlatego, że nie ma im kto podczas tego aktu pomóc. Uważała, że istnieje potrzeba założenia instytucji, w której proste kobiety mogłyby zdobyć elementarne wiadomości dotyczące higieny oraz postępowania podczas porodów trudnych i patologicznych. Księżna, organizując szkołę, pragnęła położyć kres okropnym praktykom, stosowanym przez niewyuczone, brudne babki i znachorki. W tym celu do Siemiatycz sprowadziła dwóch doktorów, obcokrajowców, którzy nauczali akuszerstwa. Szkoła przez cały okres istnienia, do 1811 r., była utrzymywana ze środków księżnej ${ }^{31}$. Najprawdopodobniej po jej śmierci przestała funkcjonować.

Podobna placówka działała przez jakiś czas w dobrach podskarbiego nadwornego litewskiego Antoniego Tyzenhauza w Grodnie. Tyzenhauz zdawał sobie sprawę, że w kraju nie ma właściwie ani jednej szkoły przygotowującej przyszłych lekarzy. Poziom istniejących wówczas wydziałów lekarskich był tak niski, że młodzi ludzie pragnący zdobywać wiedzę medyczną woleli wyjeżdżać za granicę, niż podejmować naukę w Polsce. Chcąc w jakiś sposób zahamować emigrację młodych zdolnych ludzi, postanowił - w porozumieniu z królem Stanisławem Augustem (który sfinansował całe przedsięwzięcie) - zorganizować szkołę lekarską w swoich dobrach w Grodnie. Zadaniem tym obarczył swego nadwornego lekarza Jana Emanuela Giliberta. Prace związane z organizacją szkoły lekarskiej zajęły Gilibertowi zaledwie kilkanaście miesięcy, a placówka otworzyła swoje podwoje dla adeptów pragnących zgłębiać tajniki wiedzy weterynaryjnej w 1774 r. Kolejnym dziełem Giliberta był gabinet anatomiczny, ogród botaniczny oraz lazaret dla chorej ludności. W 1775 r. szkołę weterynaryjną przekształcono w Królewską Szkołę Lekarską ${ }^{32}$. Przy niej Gilibert utworzył dom dla położnic i szkołę dla akuszerek ${ }^{33}$. Teoretyczne podstawy położnictwa prowadził sam Gilibert, który był jednocześnie dyrektorem placówki, natomiast szkoleniem praktycznym uczennic zajmowała się specjalnie do tego celu sprowadzona z Paryża wykwalifikowana akuszerka ${ }^{34}$. Nie wiadomo dokładnie, kiedy zaprzestano nauczania w szkole akuszerek w Grodnie. Prawdopodobnie miało to miejsce w 1781 r., kiedy nastąpiło przeniesienie placówki do Wilna, do uruchomionej przy Uniwersytecie podobnej placówki, zajmującej

30 Tamże, s. 501; P. S z a re j k o, Ludwik Perzyna i jego poglądy na położnictwo w 150 rocznicę zgonu (1742-1812), AHiFM-I 1963, z. 3-4, s. 241; Z. KI u k o w s k i, Organizacja pomocy lekarskiej dla włościan w ordynacji niewieściej Książąt Radziwiłłów w pierwszej połowie XIX wieku, „Archiwum Historii i Filozofii Medycyny oraz Historii Nauk Przyrodniczych" [dalej: AHiFM-II] 1925, z. I, s. 43.

31 J. Ś w i e b o d a, Średnie szkolnictwo medyczne w Galicji, AHiFM-I 1995, z.4, s. 398.

32 A. Wrzosek, Założenie Królewskiej Szkoły Lekarskiej w Grodnie za Stanisława Augusta, AHiFM-II 1925, z. 2, s. 151-157; W. B r a u e r, Polskie piśmiennictwo położnicze XVIII wieku, AHiFM-II 1933, z. 2, s. 228; M. H a n e cki, Środowisko medyczne w czasach Stanisławowskich, AHM 1973, z. 4 , s. 268.

33 Z. Fila r, Pomoc położnicza..., s. 501; J. Bitkow ski, Położnictwo w Gdańsku od XVI do końca XIX wieku, AHM I967, z.2, s. 168.

${ }^{34}$ W. B ra u e r, Polskie piśmiennictwo..., s. 229. 
się kształceniem przyszłych położnych. Do kliniki uniwersyteckiej przewieziono cały dorobek naukowy szkoły, przeszły tam też niektóre wyuczone już akuszerki ${ }^{35}$.

Proces zapoczątkowany przez arystokratów kontynuowały później postępowe koła reformatorów społecznych lub rządy zaborcze. W poszczególnych zaborach powstawały kolejne placówki, których celem było przygotowanie wykwalifikowanych akuszerek. Pierwszą szkołą powstałą z inicjatywy władz zaborczych była szkoła akuszerek we Lwowie. 10 września 1773 r. na podstawie dekretu gubernatora Galicji Pergera otwarto tam Collegium Medicum (Szkołę Medyczną). W placówce tej kształcono chirurgów, aptekarzy i położne. Organizatorem, dyrektorem i najważniejszym wykładowcą w Collegium został doktor Andrzej Krupiński. Prowadził on wykłady i ćwiczenia dla studentów oraz zajęcia dla przyszłych akuszerek w języku polskim. Wiadomości przekazywane adeptkom położnictwa dotyczyły zagadnień związanych z higieną i fizjologią porodu. Collegium Medicum istniało do 1784 r. Przez kilkanaście lat wykształcono tam dużą grupę wykwalifikowanych akuszerek ${ }^{36}$.

16 listopada 1784 r. w miejsce zamkniętego Collegium powołano do życia Uniwersytet Lwowski, zwany Uniwersytetem Józefińskim, w którym jednym z wydziałów był Wydział Lekarski. W 1790 r. rozpoczęto tam wykłady dla akuszerek ${ }^{37}$. Przyszłe położne zdobywały wiedzę teoretyczną i praktyczną w szpitalu powszechnym we Lwowie, który w kolejnych latach przekształcono w szpital krajowy. Przy nim mieściła się klinika uniwersytecka, szkoła dla chirurgów i akuszerów oraz szkoła dla położnych wraz z internatem ${ }^{38}$. Wykłady dla studentów odbywały się po polsku, niemiecku i łacinie, natomiast dla akuszerek położnictwo wykładano w języku polskim. Nauka trwała pół roku. Teorii nauczał profesor położnictwa i chirurgii Jan Walz (doktor Andrzej Krupiński już nie żył), natomiast ćwiczenia praktyczne prowadził jego asystent. Pierwszy kurs odbywał się po polsku, a drugi po niemiecku (za zgodą ówczesnych władz austriackich). Frekwencja na obu kursach, jak na ówczesne czasy, była dość znaczna, brało w nich udział po kilkanaście osób. W latach 1790-1796 szkołę akuszerek przy Wydziale Medycznym Uniwersytetu Józefińskiego ukończyły 54 kobiety39.

W 1805 r. nastąpiło przeniesienie Uniwersytetu do Krakowa, natomiast we Lwowie utworzono Liceum ${ }^{40}$. W tym samym roku w miejsce Wydziału Lekarskiego powołano Instytut Medyczno-Chirurgiczny, który połączono z owym Liceum. Instytut został urządzony na wzór szkoły średniej, miał dwuletni program nauki. Uczono w nim chirurgii, położnictwa i weterynarii. Językiem wykładowym dla studentów był niemiecki. Wykłady z położnictwa odbywały się po polsku, po-

${ }^{35}$ A. Wr zo s e k, Założenie Królewskiej Szkoły Lekarskiej..., s. 156.

${ }^{36}$ P. Szarejko, Ludwik Perzyna..., s. 241; J. Bitkowski, Położnictwo w Gdańsku..., s. 168-169; W. Z w oź d z i a k, Historia Wydziału Lekarskiego Uniwersytetu Lwowskiego, AHM 1964, z. 1-2, s. 13-14.

${ }^{37}$ W. Z wo ź d zi a k, Historia Wydziału Lekarskiego..., s. 15.

${ }_{38}$ J. Ś wi e b o d a, Średnie szkolnictwo medyczne..., AHiFM-I 1995, z. 4, s. 400.

39 T. O s t r o w s k a, M. Roliński (1776-1839) profesor anatomii Królewskiego Uniwersytetu Warszawskiego - w 210 rocznice urodzin, AHiFM-I 1986, z. 4, s. 471.

40 W. Z wo ź d z i a k, Historia Wydziału Lekarskiego..., s. 20. 
nieważ uczęszczały na nie akuszerki. Szkoła położnych przy Instytucie Medyczno-Chirurgicznym we Lwowie funkcjonowała do $1874 \mathrm{r}^{41}$

Na początku XIX w. do szkoły uczęszczało 40 słuchaczek. Podlegały one bezpośrednio nadzorowi przełożonej akuszerek. Wiadomości teoretyczne z zakresu położnictwa nadal przekazywano po polsku lub niemiecku. Nauczycielami w szkole akuszerek w tamtych latach byli m.in. Jan Machan, Ferdynand Stecher, Feliks Pfau, Adam Czyżewicz ${ }^{42}$. Teorię uczennice opanowywały z podręczników Zasady sztuki położniczej dla niewiast tejże sztuce się oddających oraz O sztuce babienia ${ }^{43}$, a umiejętności praktyczne nabywały, pełniąc dyżury w szpitalu powszechnym. Do szkoły w roku szkolnym 1870/1871 uczęszczało 57 kandydatek (38 na kurs polski i 19 na kurs niemiecki, który zawsze był mniej liczebny) ${ }^{44}$.

W 1874 r. Instytut Medyczno-Chirurgiczny został zamknięty, natomiast szkoła położnych przez rok funkcjonowała jako samodzielna placówka z nieuregulowanym statusem prawnym. Nie dysponowała ona własnym lokum, nie miała także funduszy na wynajęcie pomieszczeń oraz zezwolenia na prowadzenie praktyk w szpitalu przez kandydatki na położne. Posiadała tylko jeden etat dyrektora i jednocześnie profesora. Dopiero od 1876 r. szkoła ta miała dwuosobową obsadę kadrową. Stało się to możliwe dzięki zgodzie wydanej przez rząd wiedeński, który zgodził się opłacać odrębnego asystenta, zatwierdzanego na cztery lata. Uczennice nadal podlegały przełożonej położnych. Wówczas w szpitalu pracowało dwóch lekarzy, akuszer i asystent. Pierwszy lekarz pełnił obowiązki dyrektora i jednocześnie wykładowcy w szkole położnych. Miał także obowiązek zajmowania się chorymi w szpitalu ${ }^{45}$. W tym trudnym dla szkoły okresie funkcję dyrektora pełnił Adam Czyżewicz ${ }^{46}$.

Pod koniec XIX stulecia Iwowska szkoła akuszerek była jedną z największych i najlepiej prosperujących szkół w Galicji. We Lwowie szpital leczniczo-położniczy należał także do największych ośrodków medycznych. Rocznie przyjmował około 500 chorych (w tym dzieci) i tyle samo rodzących kobiet. Kształciło się w nim rocznie około 50 kandydatek na akuszerki ${ }^{47}$. Obserwowano ciągły wzrost liczby kandydatek do szkoły położnych. Dotychczasowy budynek, w którym kształcono przyszłe położne okazał się za mały. Dlatego w 1893 r. rozpoczęto budowę zakładu dla położnych wraz z kliniką położniczo-ginekologiczną. Od marca 1895 r. szkoła położnicza mieściła się w nowym, dużym budynku przy ulicy Piekarskiej 54 we Lwowie. Uczennice nadal odbywały praktyki w szpitalu krajowym. Wtedy oddział położniczy liczył 73 łóżka, a klinika położnicza 88 łóżek. Czas trwania nauki w szkole uległ wydłużeniu do dziesięciu miesięcy. Ponieważ nadal kształciły się Polki, Rusinki (Ukrainki) i Żydówki, zajęcia odbywały się w dwóch językach.

41 Tamże, s. 21-22.

42 Tamże, s. 24; M. Ha n e c k i, Polacy na studiach w Wiedniu, AHiFM-I 1986, z. 4, s. 456.

43 J. Ś w i e b o d a, Średnie szkolnictwo medyczne..., s. 401.

44 Tamże, s. 402.

45 Tamże, s. 403.

${ }^{46}$ L. Maria now ski, R. Dę bs ki, Zarys historii polskiego położnictwa i ginekologii, AHiFM-I 1989, z. 2-3, s. 285; M. H a n e c k i, Polacy na studiach..., s. 456.

47 J. Ś w i e b o da, Średnie szkolnictwo medyczne..., s. 403. 
Teorię wykładano w języku polskim i niemieckim, natomiast zajęcia praktyczne z akuszerii prowadzone były dla Polek w języku ojczystym, a dla Rusinek i Żydówek w języku niemieckim. Szkoła była także dobrze zaopatrzona w pomoce naukowe. Uczennice mieszkały w nowym gmachu. W ten sposób miały zapewnione odpowiednie warunki do nauki, pracy i wypoczynku. Nauka była bezpłatna. W drugiej połowie XIX w. zawód położnej był wybierany przez coraz więcej kobiet pragnących zdobyć niezależność i źródło pewnego utrzymania, dlatego do szkół tego rodzaju zgłaszało się coraz więcej uczennic. W roku szkolnym 1896/1897 do Iwowskiej szkoły akuszerek zapisały się 143 słuchaczki, a w następnym aż $226^{48}$.

W 1894 r. na Uniwersytecie Lwowskim reaktywowano Wydział Lekarski oraz otwarto Klinikę Wewnętrzną (Lekarską), Chirurgiczną oraz Klinikę Położniczą. Uroczyste otwarcie Kliniki Położniczo-Ginekologicznej odbyło się w 1899 r., a jej dyrektorem został profesor Antoni Mars ${ }^{49}$.

Na terenie Galicji oprócz szkoły Iwowskiej funkcjonowała przez cały wiek XIX szkoła akuszerek w Krakowie. Podwaliny pod rozwój nowoczesnego szkolnictwa medycznego w Krakowie położyła nowatorska działalność Komisji Edukacji Narodowej. Z jej upoważnienia Hugo Kołłątaj dokonał reformy Uniwersytetu Jagiellońskiego, reorganizując istniejące wydziały i nadając im nowoczesny charakter ${ }^{50}$. Przeobrażeniu uległ także Wydział Lekarski, przy którym w 1780 r. utworzono trzy kliniki: lekarską, chirurgiczną i położniczą. Szpital kliniczny znalazł swoje lokum w budynku klasztornym, zwanym od tej pory Collegium Świętej Barbary. Zespół klinik wraz z Collegium nazwano Szpitalem Akademickim lub Szkołą Lekarską i Cyruliczną ${ }^{51}$. Kliniką Lekarską (Wewnętrzną) kierował Andrzej Badurski, natomiast Kliniką Chirurgiczną i Położniczą zarządzał Rafał Józef Czerwiakowski, któremu Komisja powierzyła także nadzór nad całością szpitala ${ }^{52}$.

Przy Klinice Położniczej uruchomiono pierwsze wykłady dla kobiet pragnących w przyszłości „trudnić się położnictwem”. Zajęcia dla słuchaczek odbywały się od marca do wakacji w wymiarze półtorej godziny dziennie. Wykłady te z czasem przekształciły się w regularne kursy dla położnych i zaczęto je oficjalnie nazywać szkołą akuszerek. Szkoła położnych miała swoje lokum w klasztorze przy kościele Świętej Barbary ${ }^{53}$. Na pierwszy kurs położnictwa zgłosiło się zaledwie kilka kandydatek. W roku szkolnym 1790/1791 uczęszczało tylko 10 kobiet, w następnym było 16 uczennic, wszystkie pochodziły z Krakowa i jego okolic. Pierwsze przyjęte do szkoły słuchaczki były w różnym wieku; obok 19-latek były kobiety 50-letnie ${ }^{54}$. Uczennice podczas całego kursu musiały przyswoić określony zakres wiedzy teoretycznej oraz uczestniczyć w zajęciach praktycznych w klinice położniczej. Zajęcia teoretyczne często odbywały się przy łóżkach pacjentek, a w de-

${ }^{48}$ Tamże, s. 404.

${ }^{49}$ W. Z wo ź d zi a k, Historia Wydziału Lekarskiego..., z. 3, s. 195.

50 Z. Ku kuls k i. Wydział Lekarski Uniwersytetu Jagiellońskiego, AHM 1960, z. I, s. 84.

51 J. Ś wi e b oda, Średnie szkolnictwo medyczne..., s. 405.

52 Z. S k i b iń s k i, Rafał Józef Czerwiakowski, profesor anatomii w Uniwersytecie Jagiellońskim od 1779 do 1782 r., AHiFM-I 1924, z. 3, s. 328.

${ }^{53}$ W. B r a u e r, Polskie piśmiennictwo położnicze..., s. 223.

${ }^{54}$ Tamże, s. 225; J. Ś wi e b o da, Średnie szkolnictwo medyczne..., s. 405. 
monstracjach i pokazach często wykorzystywano fantom „(machinę babienia), machinę skórzaną z dwojgiem dzieci takichże do sztuki połogowania oraz szczypce żelazne do sztuki babienia" ${ }^{55}$. Na użytek uczennic szkoły akuszerek R. Czerwiakowski napisał pierwsze podręczniki: Nauka połogowania dla kobiet, Prawidła położnictwa dla cyrulików oraz Gruntowne podstawy sztuki położniczej ${ }^{56}$. Profesor Czerwiakowski piastował stanowisko kierownika Katedry Położnictwa przez 26 lat, aż do przejścia na emeryturę w roku $1805^{57}$.

Budynek Świętej Barbary był mały, stał w środku miasta, przy ruchliwej ulicy i blisko cmentarza. Takie usytuowanie szpitala źle wpływało na chorych. Dlatego w 1787 r. chorych, kobiety ciężarne i położnice przeniesiono do odnowionego budynku klasztornego karmelitów bosych, mieszczącego się na przedmieściu Krakowa, tworząc w ten sposób szpital św. Łazarza. Do tego pomieszczenia przeniesiono również Klinikę Położniczą ze Szkołą Położnych ${ }^{58}$.

Po odejściu na emeryturę Rafała Czerwiakowskiego wykładowcą w szkole położnych został Sebastian Girtler. Zajęcia z uczennicami prowadził podobnie jak poprzednik, zezwolił jednak, aby słuchaczki niektóre ćwiczenia wykonywały wspólnie ze studentami chirurgii, lecz pod kierownictwem wykwalifikowanych już akuszerek. Kolejnym kierownikiem Szkoły Położnych, a także wykładowcą położnictwa w klinice został doktor Fryderyk Colland. Klinika miała wtedy 6 łóżek położniczych oraz otrzymała prawo nadawania stopnia magistra położnictwa. Słuchaczki szkoły położnych w dalszym ciągu na zajęcia praktyczne uczęszczały do szpitala wraz ze studentami. Następnym kierownikiem szkoły i wykładowcą był lekarz Ignacy Woźniakowski, który wydłużył czas nauki w szkole położnych do dwóch lat. Ćwiczenia praktyczne za czasów Woźniakowskiego prowadził lekarz asystent ${ }^{59}$. Po śmierci Ignacego Woźniakowskiego teorię w Szkole Położnych wykładał Karol Teodor Soczyński. Tematyka wykładów dotyczyła problemów z zakresu położnictwa oraz chorób kobiecych i dzieci. Wykłady jak na owe czasy stały na wysokim poziomie. Zaczynały się obszernymi wiadomościami z zakresu historii medycyny, począwszy od starożytności, z omówieniem historii ginekologii, poprzez anatomię, fizjologię, choroby kobiece, łącznie z psychicznymi, następnie patologię aż do metod leczenia zachowawczego, operacyjnego, a nawet balneologicznego. Karol Soczyński wykładał z „rękopisu własnego w godzinach popołudniowych od 5-6.30 we wtorki i piątki, ginekologia i pediatria z teorią akuszerii w poniedziałki, środy i czwartki od 12-13.30"60.

W 1842 r. w Krakowie ukazała się Instrukcja dla akuszerek praktykujących w Mieście Krakowie i jego okręgu. Był to kodeks etyczno-moralny akuszerki. Zawierał wzory druków, które w swojej pracy miały wypełniać praktykujące położne

\footnotetext{
${ }^{55}$ W. B ra u e r, Polskie piśmiennictwo położnicze..., s. 224.

${ }^{56}$ Z. K r z y ś, Poglądy Rafała Czerwiakowskiego na wskazania do cięcia, AHiFM-I 1991, z. 3-4, s. $125-126$.

${ }^{57}$ L. Wa c h h olz, Poczet grona nauczycielskiego Wydziału Lekarskiego Uniwersytetu Jagiellońskiego od roku 1780 do 1918, AHiFM-II 1934, z. 1-2, s. 7.

58 J. Ś wi e b o da, Średnie szkolnictwo medyczne..., s. 406.

59 Tamże.

${ }^{60}$ M. Skulim ow ski, Karol Soczyński, AHM 1959, z. 2, s. 241.
} 
(dziennik czynności akuszerki, raport półroczny oraz książeczka służąca do rejestracji świadectw wystawionych kobietom, które odbyły poród) ${ }^{61}$.

Od drugiej połowy XIX w. szkołą położniczą zarządzał Maurycy Madurowicz. Pełnił również funkcję przełożonego i wykładowcy w Klinice Położniczej oraz kierował Oddziałem Położniczym. Wprowadził zakaz prowadzenia wykładów na salach chorych. Zmienił się także sposób prowadzenia edukacji akuszerek. Od 1870 r. pierwszy rok traktowano jako kurs przygotowawczy, natomiast drugi nazywano faktycznym jednorocznym cyklem nauki. Zajęcia odbywały się wyłącznie w języku polskim, a wykłady miały miejsce w tzw. semestrze zimowym, przez 10 godzin tygodniowo, a w semestrze letnim -5 godzin w tygodniu. Reszta dnia wypełniona była zajęciami praktycznymi i dyżurami w szpitalu. Egzamin końcowy (można go było zdawać tylko dwa razy) odbywał się w obecności profesora, asystenta i przedstawiciela władz krajowych. Oceny, które można było otrzymać z egzaminu to: celujący, dostateczny lub niedostateczny. Nauka była bezpłatna. Uczennice opłacały tylko 3 złote wpisowego i 10 złotych za egzamin ${ }^{62}$.

Po śmierci Madurowicza (1893) powstał problem, kto ma objąć kierownictwo kliniki, w której obok działalności naukowej i leczniczej odbywały się lekcje dla przyszłych akuszerek. W tym czasie na Uniwersytecie Jagiellońskim pracowali dwaj wybitni profesorowie ginekolodzy-położnicy: Henryk Jordan oraz Antoni Mars. Powstał spór, który z nich powinien objąć stanowisko po zmarłym M. Madurowiczu. Członkowie ówczesnego Wydziału Lekarskiego podzielili się na dwa obozy, jedni dawali pierwszeństwo H. Jordanowi, inni A. Marsowi. Ostatecznie problem rozwiązano, rozdzielając katedrę uniwersytecką od szkoły położnych. 3 czerwca 1895 r. A. Mars został zwyczajnym profesorem Szkoły Położnych, a H. Jordan zwyczajnym profesorem położnictwa i ginekologii na Wydziale Lekarskim ${ }^{63}$. W styczniu 1896 r. nastąpiło wyodrębnienie Szkoły Położnych jako samodzielnej placówki. Do jej dyspozycji w Szpitalu św. Łazarza oddano 33 łóżka dla pacjentek i 2 sale wykładowe. Oprócz sal dla pacjentek w szkole znajdowały się również pomieszczenia szpitalne dla uczennic, gabinet dyrektora, pokój dla asystenta i pokój dla przełożonej akuszerek. Część pomocy naukowych, które używane były w klinice przez położne oddano szkole. W krótkim czasie okazało się, że tak zaadaptowany budynek nie spełniał wymogów szkoły. Przede wszystkim był za mały, pacjentki rodziły na korytarzach. Powstała konieczność wybudowania dużego, przestronnego budynku. Po koniec XIX w. coraz więcej dziewcząt pragnęło zdobyć zawód położnej. Świadczyła o tym ciągle zwiększająca się liczba kandydatek. Na przykład w roku szkolnym 1894/1895 były 52 uczennice, a w roku 1896/1897 już 74 słuchaczki. Niektóre z nich otrzymywały stypendia ${ }^{64}$.

Stosunkowo wcześnie, bo już w 1781 r., założono szkołę akuszerek w Wilnie. Organizatorem i pierwszym jej kierownikiem został Mikołaj Regnier, który był

61 J. Ś wi e b o da, Średnie szkolnictwo medyczne..., s. 407.

62 Tamże, s. 408.

${ }^{63}$ L. Wa c h h ol z, Dwie obsady katedr lekarskich w Uniwersytecie Jagiellońskim w wieku XIX, AHiFM-II 1930, z. 3, s. 231-233.

64 J. Ś wi e b o da, Średnie szkolnictwo medyczne..., s. 408-409. 
również profesorem cyrulictwa i akuszerii oraz pierwszym wykładowcą położnictwa w zreorganizowanej Szkole Głównej Litewskiej65. Do celów dydaktycznych oprócz szkoły zorganizowano także w 1785 r. oddział położniczy dla dziesięciu rodzących kobiet, zlokalizowany w Szpitalu Świętego Rocha. Fundusze na ten cel pochodziły od biskupa Ignacego Massalskiego. Program wykładów z akuszerstwa (obowiązujący w szkole akuszerek w roku szkolnym 1781/1782) obejmował przede wszystkim wiadomości z zakresu udzielania praktycznej pomocy podczas porodu. Od kobiet kończących kurs wymagano, by umiały rozróżnić położenie płodu (fizjologiczne czy patologiczne), prawidłowy przebieg porodu od nieprawidłowego oraz by wiedziały, co należy robić w przypadku wystąpienia komplikacji. Profesor Mikołaj Regnier podczas swoich wykładów zwracał szczególną uwagę na umiejętność udzielenia prawidłowej pomocy podczas porodów patologicznych. Akuszerki musiały znać sposoby udzielenia prawidłowej pomocy i postępować w taki sposób, aby przy życiu zachować rodzącą i dziecko. Ponadto położne były zobowiązane udzielić fachowej pomocy ręcznej, nie uszkadzając płodu. Program z roku 1788/1789 został rozszerzony o wiadomości dotyczące: anatomii i fizjologii żeńskiego układu rozrodczego, teorii zapłodnienia, pierwszych objawów ciąży, poszczególnych etapów rozwoju płodu (ze szczególnym zwróceniem uwagi na wielkość głowy). Przyszłe położne poznawały wygląd i funkcje łożyska, zadania wód płodowych, uczyły się rozróżniać bóle fałszywe (tzw. przepowiadające) oraz właściwe bóle porodowe, opanowywały podstawowe zasady higieny i uczyły się rozpoznawać ciążę bliźniaczą. Zdobywały ponadto wiedzę z zakresu prawidłowej pielęgnacji ciężarnej, rodzącej, położnicy i noworodka. Na zajęcia praktyczne akuszerki uczęszczały do kliniki położniczej, mieszczącej się w Szpitalu Świętego Rocha, gdzie oddziałem położniczym zarządzał profesor akuszerii. W roku 1799 nastąpiło przeniesienie kliniki położniczej do Szpitala Świętego Jakuba, w którym do celów położniczych przeznaczono zaledwie 7 łóżek. Dydaktyka podzielona została wówczas na część teoretyczną, przekazywaną przez nauczycieli w formie wykładów, oraz część praktyczną, którą uczennice odbywały, uczestnicząc w dyżurach na oddziale położniczym w klinice ${ }^{66}$.

Po śmierci Mikołaja Regniera w 1800 r. kierownictwo szkoły akuszerek objął Andrzej Matusewicz, który był absolwentem medycyny w Szkole Głównej Litewskiej. Kolejnym, a zarazem ostatnim dyrektorem kliniki położniczej oraz szkoły akuszerek był Mikołaj Mianowski. Sprawował on tę funkcję przez 24 lata (od 1819 do zamknięcia Akademii Medyko-Chirurgicznej w 1842 r.). M. Mianowski był autorem jednego z najlepszych podręczników dla akuszerek. Jego Nauka sztuki położniczej dla niewiast była wielokrotnie wznawiana i polecana oraz wykorzystywana do nauczania położnictwa w podobnych szkołach w Warszawie i Lwowie ${ }^{67}$.

${ }^{65}$ L. Marian ow ski, R. Dę b ski, Zarys historii..., s. 284.

${ }^{66}$ W. B rauer, Polskie piśmiennictwo położnicze..., s. 226-228; J. Śnia de cki, Memoriał w sprawie założenia klinik na wydziale lekarskim w Szkole Głównej Litewskiej, AHiFM-II 1930, z. 2, s. $120-121$.

${ }^{67}$ M. L e ś n i e w s k i, Początki Kliniki Położniczo-Ginekologicznej Uniwersytetu Stefana Batorego w Wilnie i jej korzenie sięgające wieku XVIII, AHiFM-I 2000, z. 3-4, s. 44-45. 
Drugą placówką kształcącą położne, utworzoną na ziemiach polskich włączonych do zaboru rosyjskiego, była szkoła akuszerek w Białymstoku. Powstała jako Instytut Akuszerek w 1811 r. z inicjatywy Jakuba Feliksa Michelisa ${ }^{68}$. Nauka w tej instytucji trwała rok. W pierwszym półroczu wykładano tylko teorię, po czym organizowano egzamin. Od jego wyniku zależało, czy uczennica zostanie dopuszczona do dalszego kształcenia praktycznego. Te z kobiet, które nie zdały egzaminu pomyślnie, musiały uzupełniać wiedzę lub były usuwane z placówki. Przyszłe akuszerki czerpały wiedzę teoretyczną nie tylko z wykładów, lecz także z książek położniczych autorstwa J. F. Michelisa - Krótkiej nauki dla akuszerek oraz Nauki położniczej69.

Jedną z najstarszych szkół położniczych była Szkoła Akuszerek w Poznaniu. Założono ją w 1799 r., a pierwszy kurs zorganizowano na początku 1800 r. Nauczycielem położnictwa był doktor Liecau z Heilsberga ${ }^{70}$. Do szkoły uczęszczały Polki i Niemki. Do 1805 r. nauczanie odbywało się tylko w języku niemieckim. Było to dużym utrudnieniem dla uczennic polskich, dlatego drugim nauczycielem został doktor Bogumił Ernest Kopinus, mówiący po niemiecku i po polsku. Kurs odbywał się każdego roku w obu językach i trwał 4 miesiące. Nauka była bezpłatna, a każda uczennica w trakcie trwania kursu otrzymywała wynagrodzenie, po 3 talary miesięcznie. Mimo tak dogodnych warunków naboru, mało dziewcząt interesowało się tą szkołą. Wiązało się to z brakiem stałego wynagrodzenia za pracę w zawodzie położnej. Akuszerka dostawała zapłatę za poród od rodzącej (od bogatych więcej, od biedniejszych mniej). Od kandydatki wymagano umiejętności czytania, przynajmniej liter drukowanych, co dawało jej możliwość opanowywania wiadomości także z książek. Zdarzały się przypadki przyjmowania analfabetek. Jako przyszłe położne były mile widziane żony wiejskich nauczycieli i ekonomów oraz wykształcone mieszczki w wieku od 20 do 30 lat (z czasem wiek podwyższono do 35 roku życia). Nie przyjmowano kobiet ciężarnych i nieślubnie urodzonych, a od mężatek żądano zezwolenia od męża. Każda kandydatka, która chciała być przyjęta do szkoły, musiała przedstawić trzy zaświadczenia: pierwsze od lekarza powiatowego, który miał poświadczyć dobry stan zdrowia oraz umiejętność czytania i pisania, drugie od spowiednika - dotyczyło „moralnego prowadzenia się" i trzecie od miejscowej władzy (starostwo, gmina, magistrat), w którym określono dokładnie miejsce pracy kobiety po ukończeniu szkoły ${ }^{71}$.

Od 1816 r. Szkoła Akuszerek zwana była Instytutem Położniczym. Obowiązywał tam regulamin składający się z 5 części. W części pierwszej, zatytułowanej Ogólna organizacja, zawarto informacje, że szkoła utrzymywana jest z funduszów państwowych i można przyjmować do niej uczennice z obszarów Regencji Poznańskiej i Bydgoskiej. Do szkoły przyjmowane były także ubogie ciężarne do „odbycia” tam porodu. W części drugiej pt. Wewnętrzne urządzenie umieszczone

68 Tamże, s. 45.

69 W. B r a u e r, Polskie piśmiennictwo położnicze..., 1934, z. 2, s. 98.

70 Tamże, 1933, z. 2, s. 203.

71 E. B i a d ała, Opieka położnicza w Wielkopolsce w okresie rozbiorów Polski - na podstawie źródeł urzędowych, AHiFM-I 1991, z. 1-2, s. 47-48. 
były wymogi stawiane kadrze placówki. W myśl regulaminu, w szkole mieli być zatrudnieni: dyrektor, a zarazem pierwszy nauczyciel, drugi nauczyciel, akuszerka instytutowa i posługacz. Pracownicy ci mieszkali w szkole. Część trzecia, Nauka, regulowała sprawy nauczania. W ciągu roku odbywały się dwa czteromiesięczne kursy, jeden w języku polskim, a drugi w niemieckim. Uczennice dostawały na własność podręcznik Nauka położnicza dla państw pruskich. W trakcie nauki, po opanowaniu pewnej partii materiału, zdawały egzaminy cząstkowe, a na koniec kursu końcowy egzamin publiczny przed komisją Regencji. Na zakończenie otrzymywały świadectwo ukończenia kursu z wpisem informującym, że położna ma własny „aparat do babienia służący” oraz prawo wykonywania zawodu w ściśle określonym miejscu, przez okres pięciu lat. Niezdany egzamin wymagał powtórzenia kursu. W części czwartej regulaminu podano wymogi dotyczące uczennic. Na każdym kursie mogło się uczyć 12 dziewcząt na koszt Regencji. Miały one mieszkać i żywić się poza szkołą, na co otrzymywały co miesiąc stypendium. Po ukończeniu szkoły musiały wrócić do tego powiatu, z którego zostały skierowane i pracować tam jako położne przez pięć lat. W Instytucie Położniczym mogło kształcić się więcej osób, ale już na własny koszt. W część piątej, Ciężarne i położnice, opisane były zasady przyjmowania ciężarnych do porodu (dzięki tym kobietom uczennice miały zapewnioną ciągłą praktykę). Co miesiąc przyjmowano 6 ciężarnych, na 14 dni przed spodziewanym porodem. Położnica po urodzeniu dziecka, jeżeli nie wystąpiły komplikacje, pozostawała w instytucie jeszcze $14 \mathrm{dni}$. Uczennice miały obowiązek pełnić dyżury w dzień i w nocy. Na oddziale pomagały ciężarnym, uczyły się odbierania porodu, pielęgnowały położnice i noworodki. Przyszłe akuszerki mogły wraz ze swoimi nauczycielami chodzić do kobiet, które postanowiły rodzić $w$ domu, a nie w instytucie ${ }^{72}$.

Od 1822 r. położne oraz lekarze, chirurdzy i farmaceuci składali przed podjęciem pracy przysięgę. Położna przyrzekała, że jako chrześcijanka będzie sumiennie i wiernie wypełniać swoje obowiązki wobec rodzącej. Podczas przysięgi każda akuszerka wypowiadała następujące słowa: „[...] wszelką pomoc dawać, tych przed czasem do wyrabiania bólów nie przyniewalać, ale ostrożnie z niemi się obchodzić, i one wraz z ich małymi dziećmi tak długo w najlepszym sposobie pielęgnować, ile to do mnie należy [...], przy tym tak ubogim, jak i majętnym, skoro zawołaną zostanę, równie chętnie tak bezzwłocznie służyć, tudzież żadnej w bólach będącej niewiasty nie opuścić lub zaniedbać; dla czego też wydanym przez najjaśniejszego Króla Pruskiego [...], najmiłościwszego Króla i Pana zawartym w instrukcji dla babiących przepisom chętnie się poddaję, i takowych każdego czasu mocno trzymać się przyrzekam, jak to na wierną, pilną i sumienną akuszerkę przystoi" ${ }^{3}$.

Instytut Położniczy przez szereg lat dobrze funkcjonował. Przyszłe akuszerki były kształcone zgodnie z postępami i odkryciami naukowymi w położnictwie

72 Tamże, s. 50-51.

${ }^{73}$ E. Biadała, Przysięgi składane przez pracowników służby zdrowia w Wielkim Księstwie Poznańskiem w początkach XIX wieku, AHM 1976, z. 4, s. 451-452. 
i ginekologii, osiągniętymi w ówczesnych latach. Zmieniali się także wykładowcy. W 1826 r. etat drugiego nauczyciela otrzymał Polak, doktor Józef Antonii Jagielski, który prowadził wykłady w języku polskim. W kilka lat później wykładowcą w instytucie został lekarz-położnik Ludwik Gąsiorowski. Lekarze ci byli zdania, że czas nauki akuszeryjnej jest za krótki, dlatego proces kształcenia akuszerek został wydłużony ${ }^{74}$. Od 1844 r. kurs trwał już pół roku (wcześniej tylko 4 miesiące), po kilku latach osiem, a następnie dziewięć miesięcy. Organizowano także kursy doszkalające dla akuszerek, które wcześniej ukończyły szkołę. Celem kursu było pogłębienie wiadomości, zapoznanie się z nowymi wynalazkami, sposobami leczenia, przyczynami gorączki połogowej. Omawiano też cele i potrzeby wprowadzania zasad antyseptyki i aseptyki. Uczono metod odbierania porodu. Kursy akuszeryjne były opłacane przez same położne. Po ich ukończeniu położne zdawały egzaminy sprawdzające, początkowo co 3 lata, potem co rok. Zmienił się także proces dydaktyczny. Podręczniki wydane w języku niemieckim, były natychmiast tłumaczone na język polski. Coraz częściej zdarzały się przypadki, że do niektórych książek dołączano przepisy lub regulamin obowiązujący akuszerki w pracy zawodowej ${ }^{75}$.

W Księstwie Poznańskim, mimo systematycznego kształcenia akuszerek, ciągle brakowało położnych. Jedną z przyczyn takiego stanu rzeczy były nieregularne i niestety niskie dochody aktywnych zawodowo akuszerek. Brakował ponadto zabezpieczenia emerytalnego dla niedołężnych i starych byłych położnych. Władze pruskie, aby zachęcić kobiety do nauki w szkole „babienia” i stworzyć jakieś zabezpieczenie dla nich na starość, wydały zarządzenie o utworzeniu „Funduszu Wsparcia Akuszerek". Pieniądze przeznaczone na wsparcie dla położnych pochodziły z opodatkowania chrztów i ślubów. Każda położna, która nie mogła dalej pracować ze względów zdrowotnych lub podeszłego wieku, miała otrzymywać rentę (aż do śmierci) od gminy ${ }^{76}$. Osoby, które udzielały pomocy podczas porodów, a nie miały do tego uprawnień, zamierzano karać grzywną lub więzieniem od 4 do 8 tygodni. Każda akuszerka oprócz opłaty, jaką pobierała za usługi położnicze (co pewien czas wprowadzano nowe, wyższe cenniki), otrzymywała miesięczną pensję niezależnie od liczby odebranych porodów. Inny przepis prawny mówił o nakazie wzywania lekarza do każdego trudnego porodu. Natomiast okres odpracowania nauki akuszeryjnej w okręgu położniczym skrócono z pięciu do trzech lat. Od kandydatki, przy naborze do szkoły, nie wymagano już zaświadczenia od spowiednika, lecz tylko dokumentu od policji ${ }^{77}$.

Na przestrzeni lat szkoła wraz z częścią szpitalną została rozbudowana i cieszyła się coraz lepszą opinią. Przybywało wykwalifikowanych położnych. Coraz więcej kobiet decydowało się na odbycie porodu w szpitalach. W 1909 r. Instytut Położniczy otrzymał nazwę Wojewódzkiej Kliniki Kobiecej i Szkoły Położnictwa.

${ }^{74}$ L. K r a k o w i e ck a, Józef Antonii Jagielski lekarz poznański (19 /I 1792 - 21 XII 1865), AHM 1960, z. 2, s. 184.

${ }^{75}$ E. B i a d a ła, Opieka położnicza, s. 53.

76 Tamże, s. 48.

77 Tamże, s. 56. 
Kierownikiem został prof. Lang. W klinice zatrudnionych było wtedy 4 lekarzy,

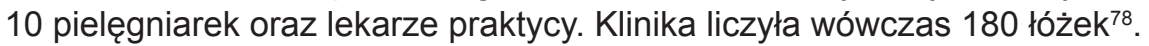

Podobna sytuacja jak w innych miastach polskich była w Gdańsku. Pomoc położnicza w tym mieście, aż do ostatnich dziesięcioleci XVIII w. spoczywała w rękach niewykwalifikowanych kobiet. Przeważnie były to kobiety w starszym wieku, które same urodziły kilkoro dzieci i posiadały elementarną wiedzę o przebiegu porodu. Brakowało im natomiast wiedzy teoretycznej. Do końca XVIII w. w Gdańsku nie było możliwości naukowego przygotowania kobiet do zawodu położnej. Władze miasta widziały jednak potrzebę wyszkolenia kobiet, które udzielałyby fachowej pomocy podczas porodu. Wychodząc naprzeciw tym potrzebom, zlecono przygotowanie projektu i zorganizowanie takiej placówki. Mimo że taki plan powstał, wstępne próby wyszkolenia akuszerek nie powiodły się. Przyczyn tego stanu rzeczy było kilka. Plan dydaktyczny stawiał bardzo wysokie wymagania zarówno uczennicom, jak i nauczycielowi. Czas trwania nauki przewidziano na pół roku, w czasie którego uczennice musiały opanować rozległą wiedzę teoretyczną i praktyczną. Lekarz prowadzący wykłady dla słuchaczek był zobowiązany chodzić z uczennicą do ciężarnych i rodzących. Dziewczęta, które pragnęły dostać tytuł zaprzysiężonej położnej, miały przez okres 3 lat uczęszczać na naukę i co rok zdawać egzamin. Te wysokie wymogi sprawiły, że sam twórca placówki nie był w stanie im sprostać i ostatecznie szkoła zaprzestała swojej działalności ${ }^{79}$.

W 1781 r. komisja Towarzystwa Przyrodniczego przedstawiła Radzie Miasta Gdańska projekt ustawy odnośnie do kształcenia położnych. Wnioskowano, aby zbudować szpital, w którym rodziłyby kobiety i jednocześnie kształciły się akuszerki. Projekt ten nie został nigdy zrealizowany, ponieważ w 1793 r. Gdańsk został włączony do Prus. W 1796 r. Towarzystwo ponownie wystąpiło do władz pruskich z wnioskiem o utworzenie Zakładu Położniczego. Wyrazem tego było otwarcie 1 grudnia 1804 r. Szpitala Położniczego i zorganizowanie pierwszego kursu szkolenia dla uczennic. Duży, przestronny budynek szpitalny mieścił się przy ul. Nowe Ogrody 11. Szpital miał własne podwórze, ogród oraz wodę. Znajdowały się w nim także pokoje dla nauczyciela i personelu szpitala. Oprócz tego były pokoje dla ciężarnych, rodzących i położnic oraz dla uczennic. Osobno została wydzielona sala porodowa i pokój do nauki ${ }^{80}$. Szpital spełniał rolę zakładu położniczego dla dwudziestu ciężarnych i prowadził szkolenia dla ośmiu uczennic jednocześnie. Zakład rozwijał się i cieszył dobrą opinią bardzo krótko, gdyż w 1807 r. podczas wojny prusko-francuskiej budynek spłonął. Placówkę przeniesiono do innego budynku, który także ucierpiał podczas wojny. Z powodu trudności finansowych władze pruskie wydały decyzję o przeniesieniu szkoły do Elbląga ${ }^{81}$.

Zakład Położniczy został w Elblągu umieszczony w niedużym budynku. W pierwszym roku istnienia szkoły w tym mieście naukę rozpoczęły zaledwie trzy

78 Tamże, s. 57

79 J. B it k ow s ki, Położnictwo w Gdańsku..., s. 171-172.

80 Tamże, s. 173-175.

81 E. S i én k o w s k i, K. R a c z y ń s k a, Dzieje nauczania medycyny w Gdańsku, AHiFM-I 2003, z. I, s. 42. 
uczennice, w kolejnych latach liczbę zwiększono do sześciu dziewcząt. Dyrektorem był doktor Franciszek Krystian Brunatti, który miał za zadanie przygotować plan przeniesienia Zakładu z powrotem do Gdańska, co uczyniono w 1819 r. ${ }^{82}$

1 marca 1819 r. nastąpiło uroczyste poświęcenie i otwarcie szpitala, który nazwano Królewskim Zakładem Położnych w Gdańsku. Urządzono go w nowym budynku przy ul. Długie Ogrody 33. Dyrektorem został doktor F. K. Brunatii. Królewski Zakład Położny pełnił dwie funkcje: leczniczą, gdyż udzielał pomocy i opieki ciężarnym i położnicom oraz dydaktyczną, ponieważ kształciły się tam akuszerki. Dziennie mogło tam przebywać 30 osób (razem z uczennicami, ciężarnymi i położnicami). W budynku tym mieszkali także: dyrektor, przełożona i położne. Szpital miał cztery pokoje przeznaczone dla uczennic i ciężarnych, jedną izbę porodową, salę do nauki i izbę z możliwością izolowania niebezpiecznie chorych położnic. Aby uniknąć zakażeń i łatwiej utrzymać czystość, ściany, podłogi, stoły i meble pomalowano olejną farbą. Na łóżkach leżały materace z włosia, składające się z trzech części, a poduszki i kołdry powleczone były czystymi powłokami. Dyrektor przywiązywał dużą wagę do utrzymania higieny na terenie podległego mu szpitala ${ }^{83}$. Do obowiązków dyrektora Zakładu, oprócz ogólnego nadzoru nad placówką, należało zarządzanie sprawami administracyjnymi, sprawowanie opieki nad personelem oraz prowadzenie wykładów dla uczennic. Przełożona zobowiązana była dbać o czystość pomieszczeń, zarządzać bielizną, pielęgnować ciężarne i położnice, asystować przy porodach podczas nieobecności dyrektora. Uczennice w Zakładzie otrzymywały mieszkanie, wyżywienie, światło i bieliznę. W zamian za to były zobowiązane dbać o czystość, szyć bieliznę, opiekować się położnicami i dziećmi, pomagać w kuchni, dyżurować kolejno w izbie porodowej w nocy. Proces nauczania składał się z części teoretycznej i praktycznej. W roku Zakład organizował trzy czteromiesięczne kursy położnicze. Każdy kurs był przeznaczony dla 16. uczennic. Wykłady prowadzono w języku polskim i niemieckim. Teorii uczono z podręczników przeznaczonych dla położnych. W kształceniu bardzo pomocne okazały się przedmioty i narzędzia położnicze, które wykorzystywano na wykładach do demonstracji (m.in. krzesło położnicze Starka i Siebolda; fantom, który przedstawiał naturalny kościec kobiety pokryty skórą, przeznaczony do ćwiczenia sposobów udzielania pomocy położniczej; miednice kobiece; wysuszone szkielety ludzkie oraz preparaty z wosku przedstawiające kanał rodny kobiety). Wiedzę praktyczną dziewczęta zdobywały, pełniąc dyżury w szpitalu. W nocy nie wolno im było spać, musiały być zawsze gotowe do przyjęcia rodzącej. Uczennice obsługiwały również porody poza szpitalem. Każda z nich po ukończeniu kursu zdawała egzamin przed dyrektorem Zakładu ${ }^{84}$.

Pod koniec 1819 r. zreformowano szkolenie i wprowadzono kursy sześciomiesięczne zamiast czteromiesięcznych. Przyjęty został drugi lekarz, który pomagał dyrektorowi w nauczaniu teoretycznym i praktycznym uczennic. Uległ także

82 J. B it k ow s k i, Położnictwo w Gdańsku..., s. 177.

${ }^{83}$ E. Biadała, Stan sanitarno-higieniczny Gdańska oraz jego siły i środki służby zdrowia w I połowie XIX wieku, AHiFM-I 1998, z. 2-3, s. 172.

84 J. B itkow ski, Położnictwo w Gdańsku..., s. 178; te n że, Działalność Szpitala Położniczego w Gdańsku w XIX i XX wieku, AHM 1971, z. 2, s. 188. 
zmianie rozkład zajęć. Wykłady teoretyczne trwały 4 godziny dziennie (dwie godziny rano i dwie po południu). Szkolenia praktyczne dotyczące pomocy położniczej odbywały się codziennie od godziny czternastej, na sali porodowej przy łóżku rodzącej, w obecności lekarza. Uczennicom nadal wolno było chodzić, wraz z lekarzem, do porodów, odbywających się poza Zakładem ${ }^{85}$. W latach 1819-1868 wykształcono 1614 położnych ${ }^{86}$.

W drugiej połowie XIX w. budynek szpitalny rozbudowano oraz zainstalowano urządzenia kąpielowe. W ten sposób poprawiono warunki sanitarne. Przyjęto regułę, że każda ciężarna musi wziąć kąpiel zaraz po przybyciu do szpitala. Do Gdańska napływało coraz więcej ludności, rodziło się także dużo dzieci, a więc wzrastało zapotrzebowanie na wyszkolone położne. Ze względu na brak miejsc w internacie Zakładu zorganizowano kursy, na które przyjmowane były kandydatki w charakterze wolontariuszek. Uczennice dochodzące na szkolenie uczyły się na własny koszt ${ }^{87}$. Przez następne lata liczba szkolonych położnych ciągle rosła, przyjeżdżały do Zakładu z różnych środowisk. Wzrost liczby uczennic i fakt, że rodzące i położnice zajmowały wspólne pokoje spowodowały, że w $1871 \mathrm{r}$. wybuchła epidemia połogowa (gorączka połogowa). Wzrosła śmiertelność wśród kobiet będących w połogu. $Z$ tego powodu szpital zamknięto na kilka tygodni i przeprowadzono dezynfekcję. Od 1880 r. Zakład funkcjonował w nowym, dużym i nowoczesnym gmachu. W latach 1881-1886 zostało wyszkolonych 256 uczennic, które otrzymały skierowania do pracy w terenie ${ }^{88}$.

Oprócz wymienionych szkół przez cały wiek XIX funkcjonowała także szkoła akuszerek w Warszawie. Była ona jedyną tego typu placówką w Królestwie Polskim. Niestety, o jej działalności znaleziono na łamach „Archiwum Historii i Filozofii Medycyny” najmniej informacji. Opieka położnicza w stolicy pod koniec XVIII w. była w stanie tragicznym. Co prawda w zestawieniach podawano, że np. w roku 1792 było 37 praktykujących „babek” ${ }^{89}$, a pod koniec stulecia 55, ale dodawano też, że wykonywały swoje „czynności w oparciu o praktykę" ${ }^{00}$. Brak wykwalifikowanych położnych szybko dostrzegły władze pruskie po trzecim rozbiorze Polski i zdecydowały o natychmiastowym uruchomieniu niezbędnej w tych warunkach szkoły. Udało się to zrobić dopiero w 1802 r. Najpierw nazwano ją Szkołą Babienia, a w latach następnych przemianowano na Szkołę Akuszerek. Utworzona była przy Instytucie Położniczym. Pierwszym dyrektorem tej instytucji został Józef Czekierski, który w 1809 r. objął również kierownictwo Katedry Chirurgii i Akuszerii na utworzonej w tym samym roku Szkoły Lekarskiej. Dyrektorowi w Szkole Babienia pomagał chirurg Franciszek Brandt ${ }^{91}$. W ciągu pierwszych dziesięciu lat istnienia tejże placówki (1802-1811) wykształcono 217 akuszerek $^{92}$.

85 J. Bitkow s ki, Położnictwo w Gdańsku..., s. 179.

86 Tamże, s. 181.

87 J. Bit k ow s ki, Działalność Szpitala Położniczego..., s. 189.

88 Tamże, s. 190.

${ }^{89}$ M. Han e cki, Środowisko medyczne..., s. 267.

90 Tamże.

91 L. Maria now s k i, R. Dę b s k i, Zarys historii..., s. 286; L. B a r g, Historiografia medyczna i nauczanie historii medycyny w Polsce do roku 1939, AHM 1978, z. 3, s. 301.

92 L. M a ri a n ow s ki, R. Dę b s ki, Zarys historii..., s. 287. 
W roku 1818 Instytut Położniczy został włączony do Katedry Położnictwa utworzonego dwa lata wcześniej Królewskiego Uniwersytetu Warszawskiego. Obowiązki dyrektora pełnił nadal Józef Czekierski. Po nim zarządzanie Katedrą objęli: Ignacy Fijałkowski, a następnie Władysław Tyrchowski93. Po upadku powstania listopadowego Uniwersytet został zamknięty. Jednak Szkoła Akuszerek najprawdopodobniej funkcjonowała nadal, bo kiedy w 1857 r. została otwarta Akademia Medyczno-Chirurgiczna, to od razu przejęła Instytut Położniczy wraz ze szkołą akuszeryjną ${ }^{94}$.

Klinika położnicza na początku lat 50. XIX wieku mieściła się w budynku Szpitala Dzieciątka Jezus na pierwszym piętrze. Przez pomieszczenia szpitalne można było przejść do Instytutu Położniczego, mieszczącego się wówczas w dwupiętrowym gmachu przy ul. Marszałkowskiej i Zgody. Parter budynku przeznaczono na cele gospodarcze i administracyjne. Na pierwszym piętrze urządzono salę porodową i oddział położniczy. Drugie piętro zajmowały chore ciężarne i położnice ${ }^{95}$. Kierownikiem został profesor Władysław Tyrchowski, któremu do pomocy przydzielono asystenta - doktora Fickiego. Studenci nazywali profesora „dziadzio”, gdyż „był to człowiek podeszły, krótkowidz ze szkłami na nosie, twarz miał jak zmiętoszoną, z grubym wąsem, mówił cicho, spokojnie, flegmatycznie. [...] Tyrchowski wykładał sumiennie, uczył nas cierpliwości przy łóżku położnicy”96. W Instytucie Położniczym Akuszerii uczono się z podręczników, przebywając bezpośrednio przy łóżku chorego oraz praktykując na fantomie skórzanym, imitującym miednicę i nogi kobiety, zakładając kleszcze porodowe. Szkoła kształciła trzy typy położnych: personel średni (tzw. akuszerki pierwszego rzędu ze „starszą" na czele), niższy (kobiety uczące się na akuszerki) i najniżej notowane tzw. „babki”, które otrzymywały przede wszystkim wykształcenie praktyczne. Po ukończeniu nauki nie dostawały dyplomu, a pracować mogły tylko na wsi97. W Królestwie Polskim fakt organizowania kursów dla babek wiejskich podyktowany był ciągłym brakiem wykwalifikowanych akuszerek. Po ukończeniu owego kursu adeptki uzyskiwały formalne uprawnienia do wykonywania tego zawodu ${ }^{98}$. Nauka w Instytucie Położniczym trwała wówczas 2 lata. Po ukończeniu edukacji adeptki wyższego i niższego rzędu zdobywały tytuł położnej dyplomowanej. Warunkiem przyjęcia do szkoły było przedstawienie świadectwa ukończenia 4 klas szkoły elementarnej. Natomiast kurs na stopień „babki wiejskiej” trwał 4 miesiące. Warunkiem uzyskania zgody na rozpoczęcie nauki na kursie była umiejętność czytania i pisania, którymi musiały się wykazać kandydatki ${ }^{99}$.

Prawie przez cały wiek XIX w Instytucie Położniczym w ogóle nie przestrzegano podstawowych zasad higieny. Przykładem był przebieg operacji wykona-

${ }^{93}$ Tamże, s. 286.

${ }^{94}$ L. B a rg, Historiografia medyczna i nauczanie..., s. 302; Z. F i l a r, Zakażenia połogowe, AHM 1961 , z. 4, s. 409.

95 Z. Fila r, Zakażenia połogowe..., z. 4, s. 408.

${ }^{96}$ L. C z a rk o w s ki, Sylwetki profesorów Wydziału Lekarskiego w Uniwersytecie Warszawskim (lata akademickie 1875/76-1880/81), AHiFM-II 1927, z. 2, s. 229.

97 L. C zarkow s ki, Sylwetki profesorów..., 1928, z. l, s. 106.

98 T. G a rl e j, Medycyna płocka przed 100 laty, AHM 1975, z. 3-4, s. 303-306.

99 W. B e r n e r, Z dziejów organizacji służby zdrowia w Łodzi, AHiFM-I 2002, z. 4, s. 484. 
nej przez doktora Ludwika Neugebauera. Przeprowadzając zabieg, w jednej ręce trzymał skalpel, a w drugiej kartkę z notatkami, z której wykładał studentom. Profesor ten nigdy nie mył rąk, ani przed, ani po badaniu chorej. Ręce wycierał w chusteczkę do nosa. Efektem takich zachowań były wielokrotnie wybuchające epidemie gorączki połogowej. Choroba ta czyniła spustoszenie na oddziale położniczym, wówczas prawie wszystkie położnicze umierały. Dyrektor Instytutu uważał, że przyczyna tkwiła w złych warunkach lokalowych szpitala ${ }^{100}$. Do wybuchu I wojny światowej Klinika Akuszeryjna (Instytut Położniczy) Uniwersytetu Warszawskiego miała tylko 15 łóżek położniczych ${ }^{101}$. W latach siedemdziesiątych XIX w. do warszawskiej Szkoły Akuszerek uczęszczały oprócz Polek także Żydówki. Liczba wykształconych wówczas Żydówek w pełni zaspokajała potrzeby ludności żydowskiej, mieszkającej w tamtych latach w stolicy ${ }^{102}$.

Pod koniec XIX stulecia w Warszawie zaczęto tworzyć zakłady dla kobiet rodzących, często nazywane przytułkami, w których przyuczano do zawodu kobiety pragnące w przyszłości wykonywać pracę akuszerki. Jednym z takich przytułków, mieszczącym się w Warszawie przy ul. Prostej 2, zarządzała i pełniła obowiązki lekarza przez prawie 29 lat doktor Anna Tomaszewicz-Dobrska ${ }^{103}$. Była ona pierwszą kobietą-lekarzem w stolicy. Wykształcenie medyczne zdobyła w Szwajcarii. Do Polski wróciła z dyplomem lekarza w 1878 r., następnie od 1880 r. pracowała w Klinice Położniczej, którą wówczas zarządzał profesor Władysław Tyrchowski ${ }^{104}$. Kiedy objęła kierownictwo jednego z przytułków położniczych, zaczęła walczyć o zmniejszenie śmiertelności wśród rodzących kobiet. Doskonale zdawała sobie sprawę, że można to osiągnąć jedynie poprzez restrykcyjne przestrzeganie higieny. Warunki pracy w przytułku były okropne. Mieścił się on w czteropokojowym mieszkaniu, bez kanalizacji i bieżącej wody. Zimą ogrzewały go dymiące piece, a kopcące lampy naftowe dawały niewiele światła. Rodzącym, co prawda, zapewniano czystą bieliznę, ale tylko wypraną, a nie wygotowaną. Mimo tak trudnych warunków Dobrska za wszelką cenę starała się przestrzegać higieny. Ciągle walczyła z niechlujstwem i niedbalstwem położnych. Przynosiło to efekty, gdyż śmiertelność wśród położnic zaczęła się stopniowo zmniejszać ${ }^{105}$. Jeżeli zdarzały się przypadki wystąpienia gorączki połogowej, wtedy przytułek zamykano na kilka dni. Pani doktor osobiście przeprowadzała dezynfekcję za pomocą chloru i karbolu. W 1889 r. przytułek przeniesiono do nowego lokum, na ul. Żelazną 55. Budynek był większy, miał gaz, wodociąg, urządzenia sanitarne, oddzielną pralnię, a co najważniejsze były możliwości odosobnienia kobiet gorączkujących i ich leczenia ${ }^{106}$. Oprócz działalności medycznej w przytułku przyuczano kandydatki

100 L. C zarkow s ki, Sylwetki profesorów..., 1928, s. 104.

101 A. Ko r d e k, Początki podyplomowego dokształcania lekarzy na ziemiach polskich w okresie zaborów, AHiFM-I 1997, z. 3, s. 221.

102 K. Waj s, S. Waj s, O szpitalach żydowskich w Warszawie, cz. I: 1799-1902, AHiFM-I 1992, z. 3-4, s. 296.

103 K. Wajs, S. Waj s, Anna Tomaszewicz-Dobrska w walce o równouprawnienie kobiet w zawodzie lekarza w drugiej połowie XIX wieku, AHM 1977, z. 2, s. 192.

104 Tamże, s. 191.

105 Z. P od gó r s k a - K I a w e, Kobiety lekarze Warszawy, AHiFM-I 1965, z. 3, s. 244.

106 K. Waj s, S. Waj s, Anna Tomaszewicz-Dobrska..., s. 192. 
do zawodu położnej. W 1905 r. szkoła przy przytułku położniczym prowadzonym przez dr A. Tomaszewicz-Dobrską uzyskała własną ustawę i moc prawną. Do 1911 r. placówka ta wykształciła około 340 położnych ${ }^{107}$. Przytułek wraz ze szkołą położnych został zamknięty w 1911 r., gdyż w tym samym roku otwarto w Warszawie dwa nowe szpitale z oddziałami położniczymi - przy ul. Żelaznej i Krajowej ${ }^{108}$.

Na łamach „Archiwum” znalazły się wzmianki o jeszcze jednej szkole, w której nauczanie odbywało się w języku polskim. Była to szkoła założona w Opolu, należącym od 1742 r. do Prus. Z pewnością w 1821 r. w Opolu odbyły się dwa kursy dla położnych. Pierwszy miał miejsce wiosną, trwał cztery miesiące, a wykłady prowadzono w języku niemieckim. Drugi został zorganizowany jesienią. Nauczanie odbywało się również przez cztery miesiące, lecz w języku polskim. Kandydatki, aby zakwalifikować się i rozpocząć naukę w szkole, musiały spełniać następujące warunki: nie mogły przekroczyć 40. roku życia, powinny okazać zaświadczenie lekarskie stwierdzające, że są zdrowe, posiadać oświadczenie od spowiednika, który zapewniał o uczciwości i dobrym, moralnym życiu dziewczyny. Kobiety te były zobowiązane mieć oświadczenie od władz miejskich lub powiatowych zapewniające, że po ukończeniu kursu zostaną zatrudnione jako położne. Ponadto kandydatki, które chciały rozpocząć naukę na kursie wiosennym, musiały umieć czytać po niemiecku, natomiast na kurs jesienny wymagana była umiejętność czytania tylko w języku polskim.

Od 1829 r. czas nauki przedłużono do ośmiu miesięcy, natomiast zmianie nie uległy warunki przyjmowania kobiet na kursy, które prowadzono już wyłącznie w języku polskim. W większości przypadków położnymi pragnęły zostać kobiety polskie. Dlatego władze pruskie zostały zmuszone do wydawania zaświadczeń urzędowych także w języku polskim. Kobiety uczyły się z podręcznika dla położnych Nauka sztuki położniczej, który został przetłumaczony z języka niemieckiego na polski. Tylko na Górnym Śląsku do tego podręcznika wydawano dodatek obejmujący polskie mianownictwo położnicze i jego odpowiedniki gwarowe, których używała ludność zamieszkująca te tereny. W Opolu już od 1811 r. obowiązywało zarządzenie nakazujące władzom pruskim miast i gmin wiejskich, aby położne kształciły się na koszt miasta. Musiały mieć zapewnione bezpłatne mieszkanie i opał. Poza tym akuszerkom przysługiwały zasiłki pieniężne w wysokości zapomóg, rozdzielanych między biednych oraz darmowe porcje żywnościowe. Zwolnione były także z różnych prac odpracowywanych na rzecz miasta, gminy lub właścicieli ziemskich. Lekarze mieli nakaz, aby do pomocy podczas porodu wzywać wyłącznie zarejestrowane położne, które mogły sprawować dalszą opiekę nad położnicą i niemowlęciem. Wysokość wynagrodzenia dla akuszerki za wykonywanie poszczególnych czynności określona została w urzędowym zarządzeniu z 1833 r. ${ }^{109}$

107 Tamże, s. 193.

108 Z. Podgórs ka-K la w e, Kobiety lekarze Warszawy..., s. 245.

109 W. B i n i s z k i e w i c z, W. K i c z k a, Z działalności położnych na Śląsku od XVII do XIX wieku, AHM 1965, z. 4, s. 383-385. 
Jak wynika z powyższych rozważań, na ziemiach polskich przez cały wiek XIX funkcjonowało zaledwie kilka szkół przysposabiających do pracy przyszłe położne. Fragmentaryczne informacje dotyczące ich działalności nie ukazują w pełni specyfiki tego typu placówek. Można jednak dzięki tym wzmiankom wyciągnąć pewne wnioski. Wszystkie opisane szkoły przyjmowały w swoje podwoje proste kobiety pragnące własną pracą zapewnić sobie środki do życia. Przypuszczalnie dla wielu z nich wybór zawodu położnej był też swego rodzaju awansem społecznym w czasach, kiedy kobiecie raczej nie wypadało pracować zawodowo. Nauka we wszystkich placówkach zapewne była bardziej nastawiona na wykształcenie określonych nawyków higienicznych i praktyczne zapoznanie się ze sposobami postępowania podczas różnych rodzajów porodów. Można śmiało stwierdzić, że zakres przekazywanej wiedzy teoretycznej był bardzo wąski, bo w ciągu trzech czy czterech miesięcy nauki nie można było przyswoić jej zbyt dużo. Wobec takich faktów nasuwa się spostrzeżenie, że tak niewiele było potrzeba, aby zwykłe domorosłe „babki” przeistoczyć w użyteczne i pomocne położne. W tym miejscu należy sobie uzmysłowić, jak długą drogę pokonało szkolnictwo przysposabiające do profesjonalnego odbierania porodów, aby mogło stać się domeną kobiet w wieku XX. 